Marija JOVANOVIĆ

Faculty of philosophy

University of Niš

Mirjana STOJNEV

Vesna KOVČIĆ
УДК 371.1:316.773(497.11Босилеград)

- оригинални научни рад -

\title{
COMMUNICATION ASPECT OF CONTEMPORARY TEACHING FROM THE PERSPECTIVE OF STUDENTS AND TEACHERS IN PRIMARY SCHOOLS FROM A BORDER MUNICIPALITY OF BOSILEGRAD*
}

\begin{abstract}
Contemporary teaching, nowadays, more than before, is significantly determined by the communication that happens during the teaching process. With its characteristics and development potential, communication affects the achievement of the objectives and tasks of educational work in the classroom and essentially determines its quality and efficiency. The specifics stemming from the immediate social context impose on communication in teaching certain characteristics that can, to a greater or lesser extent, determine its role in teaching. For these reasons, this paper uses theoretical and empirical approach to present the communication aspect of modern teaching from the perspective of its main participants: teachers and students. This paper can be even more interestingsince the empirical research was carried out on the territory of south-eastern border area of Serbia, in the municipality of Bosilegrad characterized by bilingualism and official use of Cyrillic alphabet of Serbian and Bulgarian language. The obtained results indicate a developed awareness of the role and importance of communication in ensuring effective teaching, but also significant differences in the attitudes of the participants with respect to the analyzed variables. The obtained results clearly indicate the necessity of pedagogical intervention in terms of its improvement and more regular and coherent consideration of this important issue.
\end{abstract}

Key words: communication aspect, modern teaching, student, teacher, primary school.

\section{Introduction}

Communication that takes place in the classroom significantly affects the efficiency and effectiveness of the teaching process. Given the importance of communication for the entire teaching process, it is essential that teaching process participants both understand its significance, and recognize the impor-

\footnotetext{
* The paper is the result of research within the project: „Sustainability of identity of Serbs and ethnic minorities in the border municipalities of East and Southeast Serbia" (OI 179013), carried out at the University of Nis - Faculty of Mechanical Engineering and funded by the Ministry of Education, Science and Technological Development of Republic of Serbia.
} 
tance of communication that happens during the teaching process. Numerous research and studies on educational communication as an essential factor of efficient realization of teaching indicate that communication is not at an enviable level and that school itself does not pay sufficient attention to this phenomenon, and that teachers are still under the influence of traditional teaching and one-way communication.

Successful communication largely determines the successful relationship between two or more persons. Communication conditions interpersonal relationships between individuals, allowing them to exchange experience, express their thoughts, opinions, etc. If we want a quality relationship with other people, we have to base this relationship on good and successful communication. Bratanić (2002) emphasizes that to communicate means to live, and what breathing is for biological life, communication is for social life. Teaching is based on communication, which is focused on the transfer of knowledge, experience, on the expression of attitudes, opinions and to reception of knowledge, with the aim of personality development. According to Jovanović (2009: 201215), perception and understanding of teaching material, as well as the adoption of knowledge by students depends on communication in the classroom.

In order for communication in the teaching process to be effective, it will depend on the message sender, message transmission mode, the relevance of the message, knowledge and awareness of the message recipient, the recipient motivation, fatigue, feedback, etc. As stated by Rot and Radonjić (1992), communication is successful only if there is agreement in encoding and decoding, that is, when all participants in communication associate the same meanings with the respective communication signs. However, misunderstanding in communication may arise for various reasons. The causes of ineffective communication can be numerous. During the communication in the classroom, some interference may occur that could be numerous, of varying intensity and can come from different sources. By studying literature, it can be seen that communicologists classified these interferences into objective and subjective.

Communication can be an indicator of the overall state of teaching, of its properties, but also one of the factors of its efficiency. The very orientation of teaching towards enabling a high-quality teaching communication is the foundation for the realization of an effective teaching process (Jovanović, 2009: 201-216).

\section{Theoretical approach to the problem}

\subsection{Quality determinants of classroom communication}

When we talk about quality teaching communication, it is very important to establish the characteristics which will be used to assess its effectiveness. Thus, Tubbs and Moss (1977) state that communication is effective when it is primarily characterized by comprehension, satisfaction, impact on attitudes, improvement of relations and provoking action. However, other authors claim that it takes a complex approach that will include all segments of interpersonal 
relations on which it is based. Suzic states that the key segments of effective pedagogical communication are: the ability or competency of the message sender to convey the message or to effectively implement the message content; the ability or competency of the message recipient to understand or receive a message or communication content; effective feedback; noise or distraction elimination, or their reduction to a minimum (Suzić, 2005: 175). Transfer of pedagogical communication content, that is, its effectiveness depends on who the sender is and how capable the sender is to send content that is the subject of communication, as well as on who the recipient is and how capable that person is of receiving the content of teaching communication. While in the traditional teaching, the teacher was mainly the sender of messages while the student was the recipient, in interactive teaching these roles change. The student becomes an active participant in communication, assumes both roles, and the teacher becomes an organizer of the teaching process. In this case, the feedback is not missing, and it represents an important proof of the efficiency of communication in the classroom.

According to Kovacević (2012), today's education must encourage individual advancement and training of every individual for an active life in modern society, because only in that case the needs of modern man could be met and the conditions for contemporary interpersonal communication could be created. This would primarily mean changing the position and role of students because students are still insufficiently involved in the preparation, organization and realization of the teaching process. It is necessary to provide an environment where the students could manifest their thoughts, attitudes, beliefs and feelings. In this case, the role of teacher changes - the teacher becomes a planner, organizer and implementer of teaching, as well as the communication partner for students.

In the learning process, students can often assume a passive role. Lack of interest for participation in educational activities is a common occurrence that teachers encounter in their work. In order for educational work to be successful, participation of students is the necessity, as well as an assumption of success. Students, together with teachers, must get involved in the planning, creation and implementation of the teaching process. Teachers play a major role in activating and encouraging passive learners to work. We can easily say that effective communication depends on the skill of teachers to activate and motivate students to participate. An example of good practice would be a teacher who communicates well with students, who is always there for the students, who helps them and guides them while they work on their tasks. The teacher should provoke a positive attitude in students, because only with such an attitude will a teacher create a positive atmosphere in the classroom where certainly order will subsequently exist. Only under such conditions and with such communication will both students and teachers be happy. Of course, this is not an easy task; the teacher is the person who needs to animate a large number of children, to get to know them and to establish good communication with every student.

The crucial question that arises here is what kind of classroom climate prevails in our schools? Considering that the role of teachers and students has changed over time, and that teachers are now required to have a more flexible 
way of working with students, to develop cooperative relations and strengthen positive communication, while students now have more active role in the teaching process rather than a passive one. In that regard, one might assume that this supporting, open-air, cooperative communication is taking place in our schools. As stated by Ivanek, Mikic and Karabašić (2012: 65-74), if there are cases where a student is forced to communicate, which directly makes him/her feel threatened, then this undoubtedly leads to avoidance and dishonesty in communication. Such communication can be called disturbed and uncreative, and it certainly will not lead to a good and pleasant classroom climate.

Relations between the participants in the teaching process, that is, between teachers and students is a very present and complex problem of pedagogical nature, which has existed since the first forms of organized educational work. Despite the fact that these relations have been a subject of research to many researchers, both domestic and foreign, with more or less success, they have nonetheless remained in many ways a great mystery and a challenge not only for educators and pedagogues, but also for other sciences and scientists.

\subsection{Factors of a successful classroom communication}

Communication between teachers and students is a complex process and it depends on many factors, mostly on:

- Society's attitude towards man and his development;

- The position of an individual in a certain social community;

- Sociability of an individual;

- Self-activity of an individual in different value systems;

- Personality of the teacher and his/her ability to organize and perform work (Laketa, 1998: 108-109).

In order to establish an effective educational communication, it is necessary to take into account the above factors that largely determine the relationship between teachers and students. What is particularly significant when it comes to effective communication between the participants in the teaching process is a detailed study of the communication that takes place in the classroom, so that it could be further improved.

Effective educational communication can only be discussed about if the existence of certain qualities or characteristics is identified based on which its efficiency and effectiveness would be evaluated (Jovanović, 2009). Tubbs i Moss, (1997) give a very valuable opinion when they state that communication is effective when it is primarily characterized by comprehension, satisfaction, impact on attitudes, improvement of relations and provoking action. Also, the new role of teachers, which ceases to be just lecturing, is also essential for effective communication. Suzić (2005) names the most important roles: teacher as a didactic expert, educator, scientific and educational role of the teacher, diagnostician, instructor of active teaching, coordinator, as a creator of new interpersonal relations, a creator of positive atmosphere in the classroom and the teacher as a participant in active learning process. 
The efficiency of communication is also affected by interpersonal relationships of educational communication participants. Good interpersonal relationship, according to the Bratanić (1990) is not one that is free of conflicts, but one that resolves conflict situations in an appropriate manner, enabling students to resolve conflict situations later in life as well.

Empathy is an essential prerequisite for achieving a good interpersonal relationship in classroom communication. It means that a personality is accepted and honestly understood as it is. The following are mentioned as the prerequisites for empathic communication: communication with a small number of people, a good knowledge of the person with whom you communicate, sensitivity to human behavior, developing empathy and motivation for interconnectivity (Jovanović, 2009: 368-372). In addition to the above, it is important to mention the mutual trust that should exist between participants in teaching communication. If there is no mutual trust, it could be very easy to create a barrier between the participants in communication, all of which could significantly hinder or completely disable communication.

\subsection{New roles of teachers and students in the process of classroom communication}

In addition to the new role of the teacher, the new role of the student is also important because students cease to be just listeners and the following important roles are mentioned: student as an active listener, presenter, researcher, facilitator, stimulator, supervisor, summarizer, the verifier and the evaluator, testator, manager.

Teacher, as an essential factor in the performance of educational work, is the most important personification of school. Teacher's role in modern school has completely changed compared to the role in a traditional school. First of all, a teacher must have adequate pedagogical, psychological as well as didactic and methodical education to successfully carry out the work, and to understand the requirements for changes that occur in education. Ševkušić-Mandic (1992: 290302) also discusses and emphasizes the role of teachers in the creation of social and emotional atmosphere in the class. Special emphasis is placed on the consideration of possibilities of studies which would include direct observation of the effects of teacher behavior in the classroom.

Teachers should be aware of how much good communication is important for the development of personality and how great is its significance. The very success of the educational process depends on communication between teachers and students and the quality of it. Only quality communication can give good results, that is, contribute to the success of the educational process. While teachers themselves, according to Zlatić, Marinkovic and Kundačina (2013: 616-630) should have excellent communication skills, which are necessary because of more and more complex roles and tasks that are set before them.

Communication between the participants in the teaching process should be exercised in accordance with the principles of educational work, as well as with the principles concerning building relationships among the most important factors of teaching, which are actually teachers and students. As previously 
noted, the significance of communication is underlined by the fact that successful communication in teaching is an important means to achieve the main educational goal, that is, to develop student's personality. In order for the communication between teachers and students to be good, as well as to establish a favorable social climate, the teacher is the one who should lead to such communication. Only with their knowledge, as well as with the desire and motivation to have a good and pleasant atmosphere in the classroom will the teachers develop and nurture good relations and communication with their students.

The student is one of the two most important factors in the teaching process. Student's role has transformed and changed over time, so from a passive role, student has assumed an active role and become an entity that is an essential element of education. This would primarily mean that the student is an active participant in the preparation and organization of education, and an objective evaluator of the result of this process. Through the study of educational theory and practice, we can see a clear tendency towards strengthening the active position of students. Namely, students are asked to have a more engaged and more active approach in teaching process, to participate in organizing and conducting the daily teaching activities, in accordance with their abilities and skills. This new role of students reflects a fundamental difference between the traditional and the modern school.

Favorable interpersonal relationships, good and quality communication contributes to the strengthening of the active role of students. Thus, students' responsibility for their own success and overall development is strengthened. Precisely this role allows students greater involvement in school, more active participation in communication in the classroom, as well as increased awareness of their rights, duties and responsibilities.

Active role of students means that they learn how to have more initiative, how to be more independent when learning, while teacher is the one who will create a better environment for learning, an environment where there will be no fear of penalty or low grades. This precisely ensures the participation of students in the teaching process and creates some of the most important prerequisites for the highest possible performance.

Among the trends highlighted by Skok (2005), concerning a change in the role of students, communication is also one that is mentioned. In addition to striving for democratization of relations between the participants in the teaching process, for mastering quality knowledge, for achieving greater individuality in the teaching process, one more aspiration is mentioned which is the pursuit of higher quality and more intensive communication among students and teachers and other school workers. Communication is an important indicator of mutual relations as well as the general situation in the classroom. That is why it stands out as a significant factor in assessing the degree of modernity of teaching in the school, as well as the degree of modernization of the relationship between teachers and students. The more intensive communication between the participants in the teaching process in the school, the more organized classes are, and the positive results of teaching are guaranteed. 
Communication during teaching has special attributes that must be considered. What particularly distinguishes this type of communication from the others is the very teacher-student relationship, which is by its very nature specific and different from all other interpersonal relationships. What makes this relationship more complicated is the fact that the student assumes a passive role at the very beginning, rather than being an active participant in the educational process. Although nowadays there are tendencies to change this relationship, the roles of students and teachers are still unequal, which of course makes the process more complex and makes it difficult to establish and to develop communication and to enable its participants to actively participate in it (Nikolić, 2004). The behavior of teachers towards students is an important factor affecting whether the communication will be stimulating or not. The teacher occupies an important position in the socialization of children and their motivation to participate in educational activities. Moreover, the teacher should respect every child, emphasize the positive qualities of each student, help students feel valuable, and therefore motivate them to participate in activities. An essential prerequisite for a good communication, according to Nelsen (2001) is to encourage students, which enables them to develop self-image. The teacher will encourage students by emphasizing the positive attributes and highlighting those activities that student does well.

\section{Methodological framework}

This survey aims to examine and determine whether the participants in the teaching process (students and teachers) believe that communication is important for the teaching process, that is, whether the communication in the classroom is one of the important factors for the organization and implementation of the teaching process and whether they are satisfied with it. The sample included 100 teachers and 111 students attending primary school. The survey was conducted in the municipality of Bosilegrad, which will give a realistic insight into whether the features of this border area affect the attitudes of the survey participants towards the researched issue.

\section{Results of the survey- analysis and interpretation}

Survey was focused on two tasks:

1) Determine whether teachers and students believe that communication in classroom is important for an effective teaching process.

2) Determine whether teachers and students are satisfied with the existing communication.

Table 1.- The importance of communication for the success of teaching based on students' and teachers' opinion

\begin{tabular}{|l|c|c|c|c|c|}
\hline $\begin{array}{l}\text { Importance of communica- } \\
\text { tion }\end{array}$ & $\mathrm{N}$ & $\mathrm{AS}$ & $\mathrm{SD}$ & & \\
\hline Students & 111 & 4.19 & 1.224 & \multirow{2}{*}{0.033} & \multirow{2}{*}{0.974} \\
\hline Teachers & 100 & 4.18 & 0.610 & & \\
\hline
\end{tabular}


Table 2.- Satisfaction with the existing communication among students and teachers

\begin{tabular}{|l|c|c|c|c|c|}
\hline $\begin{array}{l}\text { Satisfied with communica- } \\
\text { tion }\end{array}$ & $\mathrm{N}$ & $\mathrm{AS}$ & $\mathrm{SD}$ & $t$ & $p$ \\
\cline { 1 - 5 } Students & 111 & 3.88 & 0.470 & \multirow{2}{*}{-10.56} & $0.000 * *$ \\
\hline Teachers & 100 & 4.44 & 0.253 & \\
\hline
\end{tabular}

Table 3. - The importance of communication for effective teaching and satisfaction with communication (based on the grade that students attend)

\begin{tabular}{|c|c|c|c|c|c|}
\hline $\begin{array}{l}\text { Attitudes on communicati- } \\
\text { on }\end{array}$ & Grade & AS & SD & $t$ & $p$ \\
\hline \multirow{2}{*}{$\begin{array}{l}\text { The importance of commu- } \\
\text { nication }\end{array}$} & $6^{\text {th }}$ grade & 4,13 & 1,607 & \multirow{2}{*}{$-0,478$} & \multirow{2}{*}{0,633} \\
\hline & $8^{\text {th }}$ grade & 4,25 & 0,577 & & \\
\hline \multirow{2}{*}{$\begin{array}{l}\text { Satisfaction with commu- } \\
\text { nication }\end{array}$} & $6^{\text {th }}$ grade & 3,77 & 0,426 & \multirow{2}{*}{$-2,590$} & \multirow{2}{*}{$0,011 *$} \\
\hline & $8^{\text {th }}$ grade & 4,00 & 0,491 & & \\
\hline
\end{tabular}

Table 4. - The importance of communication for effective teaching and satisfaction with communication (based on the years of service of teachers)

\begin{tabular}{|c|c|c|c|c|c|}
\hline $\begin{array}{l}\text { Attitudes on communica- } \\
\text { tion }\end{array}$ & Years of service & AS & SD & $t$ & $p$ \\
\hline \multirow{2}{*}{$\begin{array}{l}\text { The importance of commu- } \\
\text { nication }\end{array}$} & $6^{\text {th }}$ grade & 4,13 & 1,607 & \multirow{2}{*}{4,270} & \multirow{2}{*}{$0,000 * *$} \\
\hline & $8^{\text {th }}$ grade & 4,25 & 0,577 & & \\
\hline \multirow{2}{*}{$\begin{array}{l}\text { Satisfaction with commu- } \\
\text { nication }\end{array}$} & Up to 10 years & 4,54 & 0,232 & \multirow{2}{*}{4,772} & \multirow{2}{*}{$0,000 * *$} \\
\hline & Over 10 years & 4,32 & 0,226 & & \\
\hline
\end{tabular}

The results of the research show that communication is a very important factor for the success of teaching, both based on the opinion of students and teachers. Somewhat more importance to communication was given by students $(\mathrm{M}=4.19, \mathrm{SD}=1.224)$ than by teachers $(\mathrm{M}=4.18, \mathrm{SD}=0.610)$. However, both sample groups state that communication is a very important factor for successful teaching. By checking the significance of differences in the opinions of students and teachers regarding the importance of communication for the success of teaching, no statistically significant differences were obtained $(\mathrm{t}=0.033$, $\mathrm{p}=0.974$ ). Therefore, it can be said that both samples groups (students and teachers) give equal importance to communication as one of the factors for successful teaching. This paper talked a lot about the importance of communication for the success of teaching, and these results precisely confirm this fact. Both students and teachers emphasize the importance of communication for the realization of teaching, that is, they consider it a significant factor for teaching process to succeed. These results were expected, given that many researchers have dealt with this topic and have come to similar or identical results.

The results of the research show that both sample groups are satisfied with the existing communication, that is, the obtained scores are above average both with students and teachers. Significantly higher score was obtained with teachers $(\mathrm{M}=4.44, \mathrm{SD}=0.253)$ than with students $(\mathrm{M}=3.88, \mathrm{SD}=0.470)$. By 
checking the significance of differences, a significant statistical difference was obtained $(\mathrm{t}=-10.564, \mathrm{p}=0.000)$. It is a large difference, significant on the level of $\mathrm{p}<0.01$. The obtained results show that teachers are statistically significantly more satisfied with the existing communication than their students are. This gap that exists between teachers and students indicates that, despite the many changes, there still needs to be more work done to improve and enhance the existing communication, because for communication to be considered fully successful, it is essential that both teachers and students show that they are very satisfied with it.

Table 3. presents the views on existing communication among students depending on the grade they attend. When it comes to the importance of communication for effective teaching, research results show that the greater importance to communication is given by the eighth grade students $(\mathrm{M}=4.25, \mathrm{SD}=0.577)$ than by the sixth grade students $(M=4.13, S D=1,607)$. By checking the significance of differences in the opinions regarding the importance of communication, no statistically significant differences were obtained when comparing opinions of $6^{\text {th }}$ grade students and $8^{\text {th }}$ grade students $(t=-0,478, p=0,633)$. When considering the satisfaction of students with the existing communication depending on the grade they attend, the survey results show that eighth grade students are more satisfied with communication $(\mathrm{M}=4.00, \mathrm{SD}=0.491)$ than sixth grade students $(\mathrm{M}=3.77, \mathrm{SD}=0.426)$. We need to emphasize one more time that both samples of students were very satisfied with the existing communication if one takes into account the theoretical range of the subscale. By checking the significance of differences regarding the satisfaction with communication with $6^{\text {th }}$ and $8^{\text {th }}$ grade students, a significant statistical difference was obtained $(t=-2,590$, $\mathrm{p}=0,011$ ). The significance is at the level of $\mathrm{p}<0.05$. This result shows that the eighth grade students are significantly more satisfied with the existing communication then the sixth grade students.

The survey results show that teachers who have up to 10 years of work experience give more importance to communication as a factor of successful teaching $(\mathrm{M}=4.40, \mathrm{SD}=0.432)$ than their colleagues who have work experience of over 10 years $(M=3.92, S D=0.691)$. $)$. By checking the significance of differences, a significant statistical difference was obtained based on the years of service of teachers $(t=4,270, p=0.000)$. The resulting difference is high and significant on the level of $\mathrm{p}<0.01$. This result means that teachers with work experience of up to 10 years give significantly greater importance to communication, as a factor of successful teaching, than it is the case with their colleagues who have more than 10 years of service. When considering the scores for the subscale "satisfaction with the existing communication", survey results show that teachers with less years of service (up to 10 years) are more satisfied with communication $(\mathrm{M}=4.54, \mathrm{SD}=0.232)$ than the teachers with more years of service ( $\mathrm{AS}=432, \mathrm{SD}=0.226$ ). When checking the significance of differences regarding satisfaction with communication, a significant statistical difference was obtained (at the level of $p<0.01$ ) based on the years of service of teachers $(t=4,772, p=0.000)$. This difference suggests that teachers with up to 10 years of service are significantly more satisfied with the existing communication than it 
is the case with their colleagues who have worked for more than 10 years. These results are not surprising, given that teachers with more years of service are more influenced by one-way teaching, without the possibility to engage students in the activities, and under such circumstances communication is not important nor is the method and style of communication with students, and successful communication components are not seen as significant, which means that it cannot be expected that teachers with longer work experience express satisfaction with the current status of communication.

\section{Conclusion}

Communication in the classroom is an important factor of the efficiency of teaching because its characteristics affect the way of achieving educational goals and objectives and quality of results achieved. The objective of this study was to examine whether the participants in the teaching process (students and teachers) feel that communication is an important factor for successful teaching and whether they are satisfied with the existing communication.

Summing up the results of the research, it can be concluded that communication is a very important factor for efficient teaching, based on both students' and teachers' opinion. These results were expected since contemporary teaching pays more and more attention to this phenomenon, highlighting the link between good communication in the classroom and students' satisfaction with teaching.

As for the satisfaction with the existing communication, the results show us that on average teachers are more satisfied with the existing communication than it is the case with students. This very result indicates that communication should be improved in order for both students and teachers to be alike satisfied with it, because only in this case the communication can be considered successful.

The research examined the differences in attitudes regarding communication depending on the school grade the students are in. It turned out that older students give greater importance to communication and are more satisfied with it than their younger peers. This can be justified by the fact that older students are more serious, more mature, and were much more realistic, serious and objective when completing this study. The study also found that teachers with more years of service do not emphasize the importance of communication in the classroom, and therefore they are not satisfied with the existing communication. This result is justified by the fact that teachers with longer work experience are still under the influence of traditional teaching, where one-way communication was generally the dominant one, which implied that the teacher talks while the students listen closely.

Specifics of the country border areas, which are first reflected in bilingualism and official use of Cyrillic alphabet of Serbian and Bulgarian language, had no significant effect on the attitudes regarding the investigated issue. Similarity of languages and a long tradition of living together of people in this area have led to the fact that language is not a barrier in communication. 
In the end, we can conclude that communication is an important factor of successful teaching, but as such it should continue to be improved until teachers and students are fully satisfied with it. Moreover, it is necessary to increase the awareness of teachers regarding the significance of communication for the implementation of effective teaching, its link with the satisfaction of students with teaching and with the success in school they achieve, and teachers with long work experience should be encouraged to make changes and improve their work. Furthermore, recommendations can be made to include a larger number of teachers and students in future surveys, in order to be able to have more accurate and reliable conclusions regarding current communication in our schools, to check the satisfaction of the participants in teaching communication and to have them recommend any changes in order for communication in classrooms to improve more.

\section{References}

1. Bratanić, M. (1990). Mikropedagogija-interakcijsko-komunikacijski aspekt odgoja. Zagreb: Školska knjiga.

2. Bratanić, M. (2002). Paradoks odgoj. Zagreb: Hrvatska sveučilišna naknada.

3. Zlatić, L., Marinković, S., i M. Kundačina (2013). Sadržaji o komunikacionoj kompetentnosti u obrazovanju učitelja i nastavnika. Nastava i vaspitanje. 62(4), 616-630.

4. Ivanek, P., Mikić, B. i J. Karabašić (2012). Razredna klima kao faktor sukoba u komunikaciji između nastavnika i učenika. Sportske nauke i zdravlje. 2(1), 65-74.

5. Jovanović, M. (2009). O postojećoj komunikaciji u nastavi i o neophodnim promenama. Nastava i vaspitanje. 2, 201-216.

6. Jovanović, M. (2009). Pedagoška komunikacija kao faktor efikasnosti nastave. Pedagoška stvarnost. br. 3-4, 368-383.

7. Kovačević, P. (2012). Komunikacija i interakcija u nastavi matematike. Norma. 171-192.

8. Laketa, N. (1998). Učitelj-nastavnik-učenik. Užice: Učiteljski fakultet u Užicu.

9. Nikolić, R. (2004). Mogućnosti savremene škole u razvijanju komunikativnih sposobnosti učenika. U: Komunikacija i mediji. Učiteljski fakultet u Jagodini, Institut za pedagoška istraživanja u Beogradu, 191-198.

10. Nelsen, Dž. (2001). Pozitivna disciplina. Čačak: Inter Gradex Trade.

11. Rot, N. i S. Radonjić (1992). Psihologija. Beograd: Zavod za udžbenike i nastavna sredstva.

12. Skok, P. (2005). Učenik u savremenoj nastavi - jučer, danas, sutra. Lučko: Mentor.

13. Suzić, N. ( 2005). Pedagogija za XXI vijek. Banja Luka: TT Centar.

14. Tubbs, S. L. \& S. Moss (1977). Human Communication. New York: Random House.

15. Ševkušić-Mandić, S. (1992). Stil ponašanja učitelja i socijalno-emocionalna klima u odeljenju. Nastava $i$ vaspitanje. 3, 290-302. 
Марија Јовановић

Мирјана Стојнев

Весна Ковчић

\section{КОМУНИКАЦИОНИ АСПЕКТ САВРЕМЕНЕ НАСТАВЕ ИЗ УГЛА УЧЕНИКА И НАСТАВНИКА ОСНОВНИХ ШКОЛА ПОГРАНИЧНЕ ОПШТИНЕ БОСИЛЕГРАД}

Резиме: Савремени наставу данас, више него раније, значајно одређује комуникациони процес који се у њему остварује. Својим особеностима и развојним нивоом комуникација утиче на оствариване ичиьева и задатака васпинообразовног рада у настави и суштински одређује юен квалитет и ефикасност. Специфичности које произилазе из непосредног друштвеног контекста намећу наставној комуникацији поједине одлике које могу у већој или мањој мери детерминисати ьену улогу у настави. Из ових разлога у раду је теоријскоемпиријским приступом представљен комуникациони аспект савремене наставе из угла њених главних актера: наставника и ученика. Посебна вредност рада произилази из чињенице да је емпиријско истраживање извршено на територији југоисточног пограничја Србије, општини Босилеград коју карактерише двојезичност, односно службена употреба ћириличних писама српског и бугарског језика. Утврђени резултати указују на развијену свест о улози и значају комуникачије за обезбеђивање ефикасности наставе али и значајне разлике у ставовима актера с обзиром на анализиране варијабле. Утврђени резултати недвосмислено указују на неопходност педагошке интервенције у смислу њеног унапређивања и правилнијег и усклађенијег сагледавања овог значајног проблема.

Кључне речи: комуникациони аспект, савремена настава, ученик, наставник, основна школа.

Примљено: 29. 12. 2016. године.

Одобрено за штампу: 17. 01. 2017. године. 